NBSIR 83-2737

\title{
Computer Analysis of A Pressurized Stairwell
}

U S. DEPARTMENT OF COMMERCE

National Bureau of Standards

National Engineering Laboratory

Center for Fire Research

Washington, DC 20234

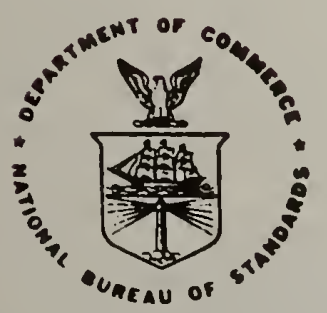

$-a c$

100

U.S. DEPARTMENT OF COMMERCE

.456

NATIONAL BUREAU OF STANDARDS

83-2737

1983

C.2 

John H. Klote

U.S. DEPARTMENT OF COMMERCE

National Bureau of Standards

National Engineering Laboratory

Center for Fire Research

Washington, DC 20234

and

Xavier Bodart

Service Securite - Feu

Station de Recherche

Centre Scientifique et

Technique du Batiment

Champs Sur Marne, France

August 1983

U.S. DEPARTMENT OF COMMERCE, Malcolm Baldrige, Socrotary NATIONAL BUREAU OF STANDARDS, Emest Ambler, Director 



\section{Page}

LIST OF FIGURES.................................. iv

LIST OF TABLES.................................... v

Abstract..........................................

1. INTRODUCTION................................... 2

2. NBS COMPUTER PROGRAM............................ 3

3. TEST SERIES $\ldots \ldots \ldots \ldots \ldots \ldots \ldots \ldots \ldots \ldots \ldots \ldots \ldots \ldots \ldots \ldots \ldots \ldots \ldots \ldots \ldots \ldots$

4. FLOW MODEL.................................... 7

5. COMPUTER SIMULATION.............................. 9

6. REEVALUATION OF FLOW EXPONENTS IN SMOKE CONTROL DESIGN........ 10

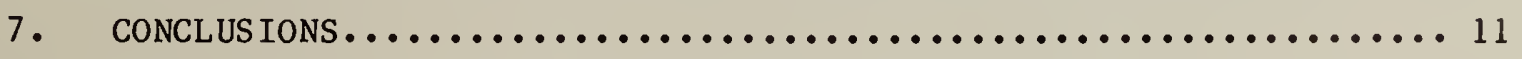

8. REFERENCES..................................... 12

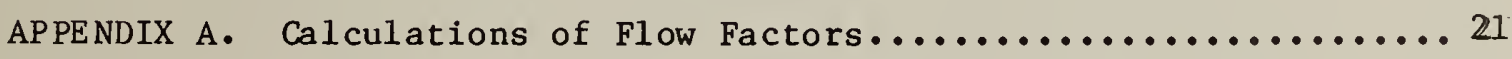

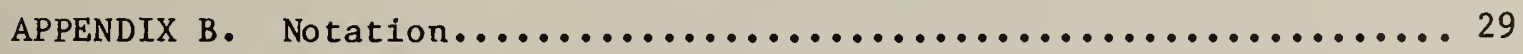

APPENDIX C. Unit Conversions........................... 30 


\section{LIST OF FIGURES}

\section{Page}

Figure 1. Idealized flow model for CSTB tower $\ldots \ldots \ldots \ldots \ldots \ldots \ldots$

Figure Al. Duct connection between floors of CSTB tower ........27

Figure A2. Floor plan of ground floor of CSTB tower $\ldots \ldots \ldots \ldots \ldots 28$ 


\section{LIST OF TABLES}

$\underline{\text { Page }}$

Table 1. Flow factors and flow exponents between the building and the outside obtained by regression analysis ......... 14

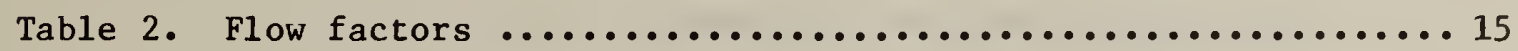

Table 3. Test schedule including supply and exhaust air flow

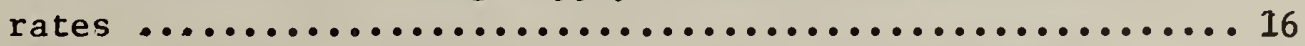

Table 4. Comparison of measured and calculated pressure differences ................................... 17

Table 5. Flow factors from building to the outside based on a flow

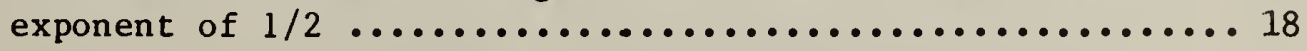

Table 6. Comparison of calculated pressure differences for a flow exponent of the exterior wall, $\mathrm{n}_{\mathrm{BOI}}$, of $1 / 2$ and greater than $1 / 2$ 

COMPUTER ANALYSIS OF A PRESSURIZED STAIRWELL

John H. Klote and Xavier Bodart

Abstract

In recent years pressurized stairwells have been incorporated in buildings in an effort to provide smoke free exits during building fires. This paper compares the results of tests conducted in a pressurized stairwell at Champs Sur Marne, France, with computer analysis using a computer code developed at the National Bureau of Standards (NBS). A second paper is planned which will compare the NBS program with the Centre Scientifique et Technique du Batiment (CSTB) program for the same series of tests. Agreement between the NBS computer simulation and the test data was good for all tests analyzed. The appropriateness of using exclusively a flow exponent of $1 / 2$ for smoke control design is reevaluated, and is found to have only a slight effect on the results of a computer simulation.

Keywords: Air movement; computer programs; egress; elevator shafts; escape means; modeling; pressurization; simulation; smoke control; stairwells. 


\section{INTRODUCTION}

The concept of stairwell pressurization has been developed in recent years as a means to provide a smoke free exit during building fires. Ideally, a pressurized stairwell maintains a positive pressure with respect to the rest of the building which prevents smoke infiltration into the stairwell when the stairwell doors are closed.

The work reported on herein is part of an investigation of pressurized stairwells undertaken jointly by the National Bureau of Standards (NBS) in the United States and the Centre Scientifique et Technique du Batiment (CSTB) in France. The objective of this paper is to compare the results of tests on a pressurized stairwell at Champs Sur Marne, France, with results calculated by computer analysis using the NBS program for analysis of pressurized stairwells [1]. In addition, the appropriateness of exclusively using flow exponents of $1 / 2$ for smoke control design is reevaluated. A second paper is planned which will compare results calculated by the NBS program with those of the CSTB program [2] for the same series of tests. This report is not intended as a design guideline, however design information is available from Klote and Fothergill [3]

The National Research Council (NRC) of Canada [4-9] has performed a number of tests on buildings to evaluate the effectiveness of various approaches to smoke control by measuring levels of pressurization produced by these systems. These tests and others $[10,11]$ by the NRC have also provided considerable information concerning leakage areas for walls and floors of commercial buildings. Cresci [12] has performed a computer analysis of tests 
on a 22-story pressurized stairwell located in New York City. He also used a scale model to investigate air flow and friction losses due to vertical air flow through the stair shaft.

The tests described in this paper differ from these earlier ones in that the flow network throughout the building was carefully analyzed and controlled and the characteristics of the flow paths were determined throughout the building. This flow network and the characteristics of the flow paths were then used in the computer analysis to determine the level of agreement between the computer program and test data.

\section{NBS COMPUTER PROGRAM}

The NBS program [1] was specifically written for the analysis of pressurized stairwells and pressurized elevators. Data input has been designed to minimize the quantity of required data and still maintain a high level of generality in the computer model. In this program a building is represented by a network of spaces or nodes, each at a specific pressure and temperature. Stairwells and other shafts are modeled by a vertical series of spaces, one for each floor.

Air flows through flow paths from spaces of high pressure to spaces of lower pressure. The principle flow paths are doors and windows which may be opened or closed. Air flow can also occur through cracks in partitions, floors, exterior walls and roofs. Such air flow can be empirically described by the flow equation 


$$
\dot{\mathrm{m}}=\mathrm{K}(\Delta \mathrm{P})^{\mathrm{n}}
$$

where $\dot{\mathrm{m}}=$ mass flow rate of air through the path

$\mathrm{K}=\mathrm{flow}$ factor

$\Delta P=$ pressure difference across the flow path

$\mathrm{n}=$ flow exponent

The flow factor, $K$, depends on the shape and cross sectional area of the flow path. The flow exponent, $n$, can vary between $1 / 2$ and 1 . Large openings and all but extremely narrow cracks have a flow exponent of $1 / 2$.

In the NBS computer model, air from outside the building can be introduced by a pressurization system into any level of a shaft or even into other building spaces. This allows simulation of stairwell pressurization. The steady state pressures and flows throughout the building are obtained by solving the air flow network, including the driving forces (1.e., wind, pressurization system, inside/outside temperature difference, etc.).

The assumptions upon which the program was developed are:

1. Each space is considered to be at one specific pressure and one specific temperature.

2. The flows and flow paths are assumed to occur at mid-height of each level (or floor). 
3. The net air supplied by the air handling system or by the pressurization system is assumed to be constant and independent of building pressure.

4. The outside air temperature is assumed constant.

5. The outside static air pressure at ground level is assumed to be $101,325 \mathrm{~Pa}$, standard atmospheric pressure. (This can be changed by modifying the program. However, this was not necessary for the analysis discussed in this paper.)

Computer input consists of:

1. outside air temperature,

2. air temperatures throughout the building,

3. outside wind velocity, and

4. description of network including flow factors and flow exponents for all connections.

Computer output consists of steady state flows and pressures throughout the entire building network. 


\section{TEST SERIES}

The stairwell pressurization tests were performed in a tower located at the CSTB Research Station, Champs Sur Marne, France. The top story of the nine story building was not connected to the stairwe1l, so that the stairwell was effectively eight stories.

The tests, described in detail by Hognon [13], were divided into three groups :

1. six tests without overpressure relief,

2. seven tests with a non-powered exhaust duct for overpressure relief, and

3. twenty-one tests with a barometric damper for overpressure relief.

The concept of overpressure relief is to prevent excessive stairwell pressures when all stairwell doors are closed by relieving some of the stairwell supply air to either the building or to the outside. This concept is discussed in more detail by Klote $[14,15]$.

Extensive modifications were made to the tower, including installation of a pressurization system along with the two means of overpressure relief. A variable speed supply air fan was used so that the stairwell could be pressurized at several different air flow rates. 
Pressure differences, pressurization air flow rates, wind speed and direction, and temperatures were recorded on strip chart recorders. Temperatures were recorded continuously throughout the test series. The pressure differences and flow rates were recorded sequentially during each test on the same recorder. The period of time required to record the data for a single test was approximately 90 seconds. The wind speed and direction fluctuated throughout the tests. During all of the tests, the temperature difference between the building and the outside was insignificantly small.

Even though the wind data were recorded continuously, the wind data were not cross referenced with the other data so that specific wind data is not available for the tests. During the tests without overpressure relief, the maximum wind speed was $18 \mathrm{~km} \mathrm{~h}^{-1}$. During the tests with the non-powered exhaust, the maximum wind speed was $23 \mathrm{~km} \mathrm{~h}^{-1}$. The performance of the barometric damper was found to be highly dependent on wind velocity, and accordingly these tests could not be analyzed by the NBS computer program. The wind was also a significant factor for two of the tests with the non-powered exhaust duct, rendering these tests unsuitable for analyses.

\section{FLOW MODEL}

Considerable effort was extended in modifying the tower so that the air flow network of the tower would be represented by the idealized flow model illustrated in figure 1. This was done to facilitate the evaluation of the air flow paths. 
Transom windows were located in the exterior tower walls. For the case where the transom windows closed, the flow factors, $\mathrm{K}_{\mathrm{BOI}}$, and flow exponents, $\mathrm{n}_{\mathrm{BO}}$, between the bullding and the outside at any level $\mathrm{i}$ were obtained by regression analysis of pressure difference and flow data provided by Hognon [13] and are listed in table 1. For the rest of the flow paths in the building the flow areas were relatively large, and therefore a flow exponent of $1 / 2$ was used. A summary listing of these flow factors is provided in table 2 and detailed descriptions, areas and calculations of the flow paths are provided in Appendix A.

For a flow exponent of $1 / 2$, the flow equation becomes the orifice equation.

$$
\dot{\mathrm{m}}=\mathrm{AC} \sqrt{2 \rho \Delta \mathrm{P}}
$$

where $A=$ flow area

$C=$ flow coefficient

$\rho=$ density of air in the flow path

The flow coefficient is generally in the range of 0.6 to 0.7 for cracks in buildings, the actual value being dependent on the geometry of the flow path. For an open door of a pressurized stairwe11, Cresci [12] found that the flow coefficient was half or less than that which would have been anticipated. This was attributed to the complex flow patterns that existed near the open doors. In fact, Crescl observed stationary vortices on various floor landings of a scale model of the stairwell he analyzed. Based on Cresci's observation, a flow coefficient $C=0.30$ was chosen for this test series for 
the open stairwell doors where the air flows were relatively high. This occurred when the ground floor door was open or when another stairwell door was open and the transom window on that floor was also open. When the transom window was closed on the floor with an open stairwell door, the resulting flow through the stairwell doorway was much lower. In this case it was expected that the flow patterns in the vicinity of the open doorway would be less complex and accordingly larger flow coefficients were used.

The ducted supply system for the stairwell had four injection points, one located between the ground floor and the lst floor and the others at the 2nd, $4 \mathrm{th}$, and 6 th floors, and the ducted exhaust system had three inlets, one each on the 1st, 3rd, and 5th floors. Before the tests, the supply system was balanced so that the supply air was approximately evenly divided between the injection points, and the exhaust system was also balanced so that the exhaust air was approximately evenly divided between the exhaust inlets. Accordingly, for the computer analysis the total measured air flow rates were evenly divided amoung injection points or the exhaust inlets, as appropriate.

\section{COMPUTER SIMULATION}

Eleven of the stairwell pressurization tests conducted at the CSTB Research Station were analyzed by the NBS computer program. Because of the lack of specific wind data for each test (see section 3), the tests analyzed were limited to those tests for which the wind effects were minor. This comparative analysis includes all the tests without overpressure relief and five of the seven tests with the non-powered exhaust duct but none of the tests with the barometric damper. 
Table 3 is a schedule of the tests analyzed by the NBS program including measured air supply and exhaust rates. Table 4 is a comparison of measured and calculated pressure differences for these tests.

It is apparent that the results of the computer simulation are in good agreement with the test data.

An attempt was made to simulate one of the tests where wind was a significant factor. The variation in wind velocity with height above the ground was modeled by the power law as provided in the NBS program. Unfortunately, the results were less than satisfactory. Possibly this was due to local wind effects near the ground. Further research is needed with regard to the effects of wind on such pressurization systems.

\section{REEVALUATION OF FLOW EXPONENTS IN SMOKE CONTROL DESIGN}

The values of the flow factors and flow exponents between the building and the outside were obtained by regression analysis (table 1). All of these flow exponents are greater than $1 / 2$.

However, for smoke control design a flow exponent of $1 / 2$ is commonly used for all flow paths. This simplifies calculations both in itself and by allowing the use of equivalent flow areas for systems of flow paths in series, parallel or both.

The NBS computer program was used to reevaluate the $1 / 2$ exponent. Table 5 lists flow factors between the building and the outside which are based on a 
flow exponent of $1 / 2$. These flow factors were evaluated at flows and pressures that were calculated in the computer analysis of test 1 with the flow factors and exponents listed in table 1. Therefore, the computer simulation of test 1 with the flow exponent of $1 / 2$ was esentially identical to that where the flow exponents were obtained by regression anlaysis.

Table 6 is a comparison of calculated pressure differences for tests 3 and 5 with flow exponents of $1 / 2$ and flow exponents obtained by regression analysis. It is apparent that the change in the flow exponent causes only a slight change in the results of the computer simulation.

\section{CONCLUSIONS}

1. The good agreement between the pressure differences calculated by the NBS computer program and the test data indicate that the assumptions of the NBS computer program are reasonable for an analysis of a pressurized stairwell under circumstances similar to the tests described in this paper when wind is not a significant factor.

2. In situations where wind is a significant factor, the NBS computer program was not capable of performing a satisfactory simulation. Further research is needed with regard to wind effects.

3. An analysis with all flow exponents at $1 / 2$ yields acceptable results for design purposes. However, for experimental research more accurate evaluation of flow exponents may be appropriate for very narrow cracks. 
4. The use of a relatively low flow coefficient $(C=0.30)$ for open stairwell doors with large flow rates yielded computer simulations in good agreement with measurements.

\section{REFERENCES}

[1] Klote, J.H., A Computer Program for Analysis of Pressurized Stairwells and Pressurized Elevator Shafts, Nat. Bur. Stand. (U.S.), NBSIR 80-2157, Jan. 1981 .

[2] Rilling, J., Smoke Study, 3rd Phase, Method of Calculating the Smoke Movement Between Building Spaces, Centre Scientifique et Technique du Batiment (CSTB), Champs Sur Marne, France, Sept. 1978.

[3] Klote, J.H. and Fothergill, J.W., Design of Smoke Control Systems for Buildings, Nat. Bur. Stand. (U.S.), NBS-Handbook 141, June 1983.

[4] Tamura, G.T., Experimental Studies on Pressurized Escape Routes, ASHRAE Transactions 1974, Vol. 80, Part 2, pp. 224-237, 1974.

[5] Tamura, G.T. and Shaw, C.Y., Experimental Studies of Mechanical Venting for Smoke Control in Tall of fice Buildings, ASHRAE Transactions 1978, Vol. 86, Part 1, pp. 54-71, 1978.

[6] Tamura, G.T., Experimental Studies on Exterior Wall Venting for Smoke Control in Tall Buildings, ASHRAE Transactions 1978, Vo1. 84, Part 2, pp. 204-215, 1978.

[7] Tamura, G.T., Exterior Wall Venting for Smoke Control in Tall office Buildings, ASHRAE Journal, Vol. 20, No. 8, pp. 43-48, August 1978.

[8] Tamura, G.T., A Smoke Control System for High-Rise office Buildings, ASHRAE Journal, Vo1. 24, No. 5, pp. 29-32, May 1982.

[9] Tamura, G.T., The Performance of a Vestibule Pressurization System for the Protection of Escape Routes of a 17-Story Hotel, ASHRAE Transactions 1980, Vo1. 86, Part 1, pp. 593-603, 1980.

[10] Tamura, G.T. and Shaw, C.Y., Air Leakage Data for the Design of Elevator and Stair Shaft Pressurization Systems, ASHRAE Transactions 1976, Vol. 82, Part 2, pp. 179-190, 1976.

[11] Tamura, G.T. and Shaw, C.Y., Studies on Exterior Wall Air Tightness and Air Infiltration of Tall Buildings, ASHRAE Transactions 1976, Vol. 86, Part 1, pp. 122-134, 1976. 
[12] Cresci, R.J., Smoke and Fire Control in High-Rise office Buildings Part II: Analysis of Stair Pressurization Systems, Symposium on Experience and Applications on Smoke and Fire Control at the ASHRAE Annual Meeting, June 1973, Louisville, Kentucky, ASHRAE, Atlanta, GA, pp. 16-23, 1973.

[13] Hognon, B., Prevention of Smoke Build-Up in the Stairwells of High-Rise Buildings by Pressurization, Centre Scientifique et Technique du Batiment (CSTB), Champs Sur Marne, France, Aug. 1981.

[14] Klote, J.H., Stairwell Pressurization, ASHRAE Transactions 1980, Vol. 86, Part 1, American Society of Heating, Refrigerating and AirConditioning Engineers, Inc., New York, NY, 1980.

[15] Klote, J.H., Smoke Control by Stairwell Pressurization, Engineering Applications of Fire Technology Workshop, Society of Fire Protection Engineers, Boston, MA, to be published.

[16] Edel'chik, I.E., Handbook of Hydrolic Resistance - Coefficients of Local Resistance and of Friction, U.S. AEC, 1966. 
Table 1. Flow factors and flow exponents between the building and the outside obtained by regression analysis

$\begin{array}{cccc}\text { Floor (i) } & \begin{array}{c}\mathrm{K}_{\mathrm{BOi}} \\ 1\end{array} \frac{\mathrm{kg} \mathrm{s}^{-1} \mathrm{~Pa}^{-1 / \mathrm{nBOi}}}{0.0104} & \frac{\mathrm{n}_{\mathrm{BOi}}}{0.55} & \begin{array}{c}\text { Correlation } \\ \text { Coefficient }\end{array} \\ 2 & 0.00684 & 0.64 & 0.99 \\ 3 & 0.00720 & 0.59 & 0.94 \\ 4 & 0.00468 & 0.68 & 0.98 \\ 5 & 0.0132 & 0.58 & 0.96 \\ 6 & 0.00312 & 0.77 & 0.99 \\ 7 & 0.00456 & 0.70 & 0.99\end{array}$




\section{Flow Factor}

\begin{tabular}{|c|c|c|c|}
\hline & Symbol & $\left(\mathrm{kg} \mathrm{s} \mathrm{s}^{-1} \mathrm{~Pa}^{-1 / 2}\right)$ & Rema rks \\
\hline $\mathrm{K}_{\mathrm{SBi}}$, & for $i=0$ to 7 & 0.0252 & stairwell door closed \\
\hline $\mathrm{K}_{\mathrm{SBi}}$, & for $i=1$ to 7 & 1.48 & $\begin{array}{l}\text { stairwell door open when } \\
\text { transom on floor } i \text { is closed }\end{array}$ \\
\hline $\mathrm{K}_{\mathrm{SBi}}$, & for $i=1$ to 7 & 0.739 & $\begin{array}{l}\text { stairwell door open when } \\
\text { transom on floor } i \text { is open }\end{array}$ \\
\hline $\mathrm{K}_{\mathrm{SBO}}$, & ground floor & 0.628 & stairwell door open \\
\hline $\mathrm{K}_{\mathrm{BO} i}$, & for $t=1$ to 7 & 0.310 & transom window open \\
\hline $\mathrm{K}_{\mathrm{SO}}$, & for $1=0$ to 8 & 0.00344 & \\
\hline $\mathrm{K}_{\mathrm{Fi}}$ & for $i=2$ to 7 & 0.0123 & \\
\hline $\mathrm{K}_{\mathrm{BOO}}$, & ground floor & 2.50 & \\
\hline
\end{tabular}

\section{Notes:}

1. Calculations of these flow factors are provided in Appendix A.

2. For definition of symbols, see Appendix B. 


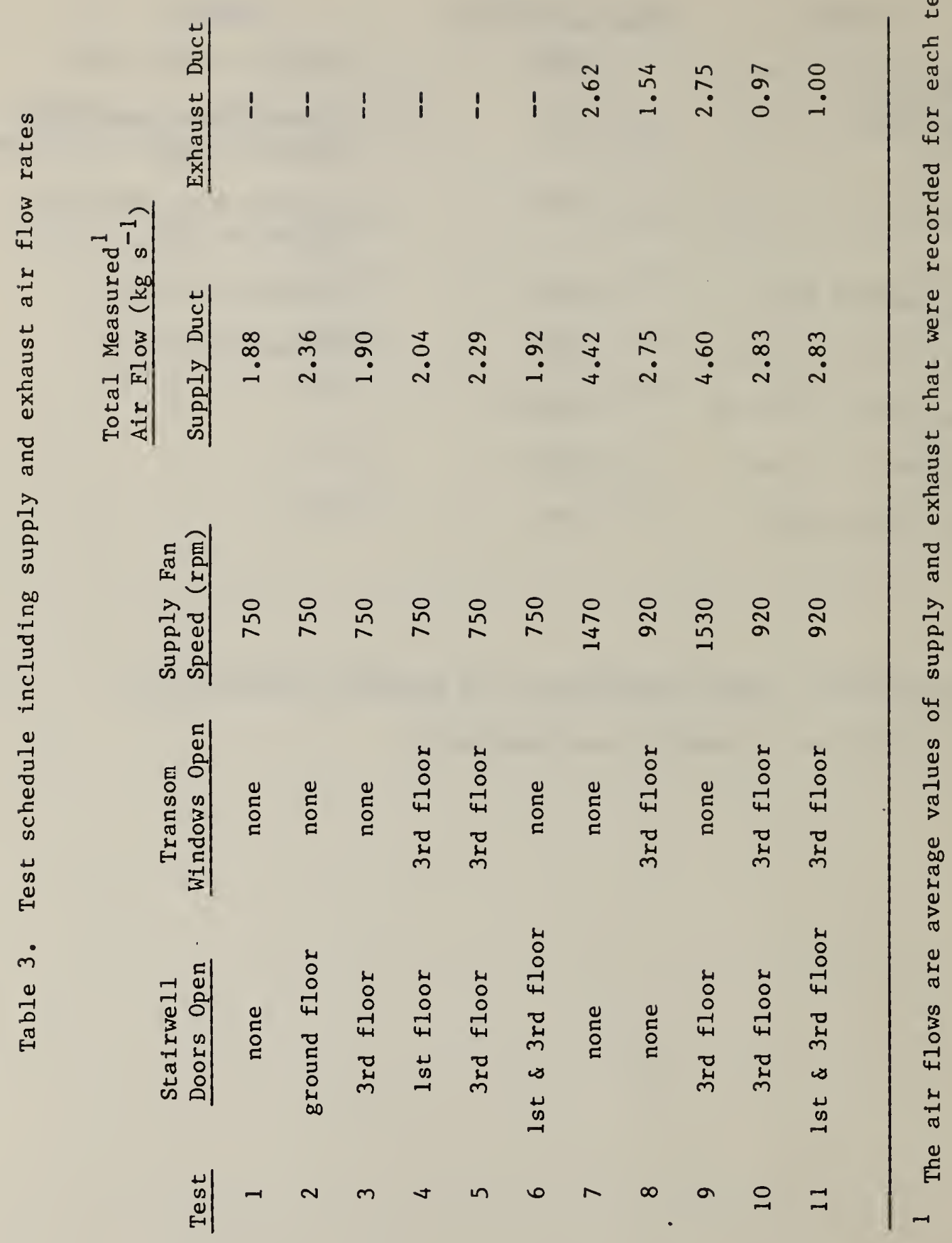




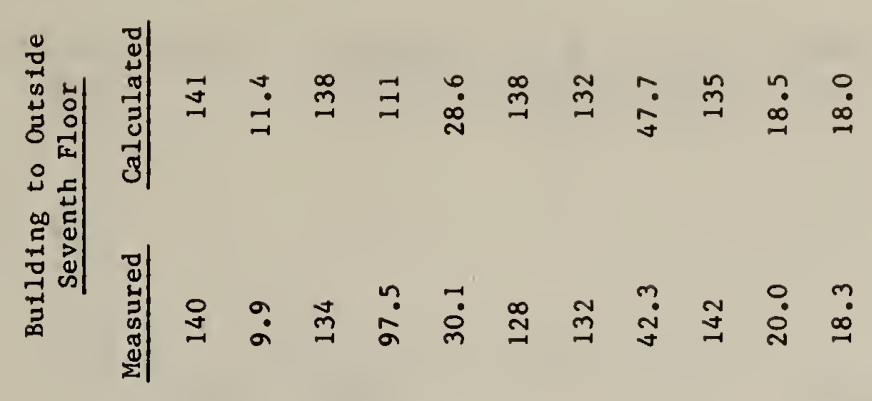

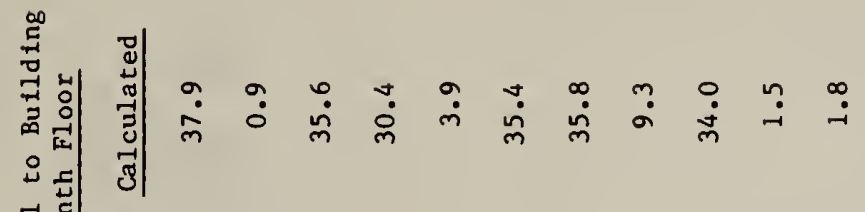

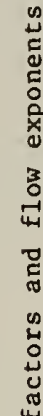

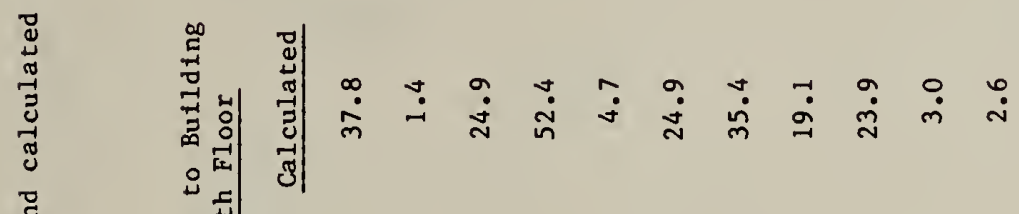

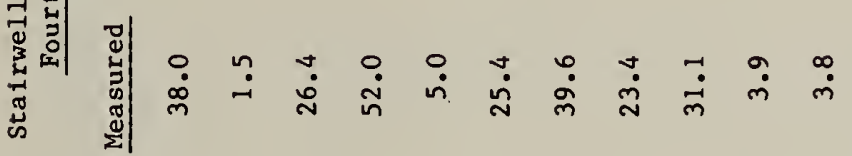

莡

品

离

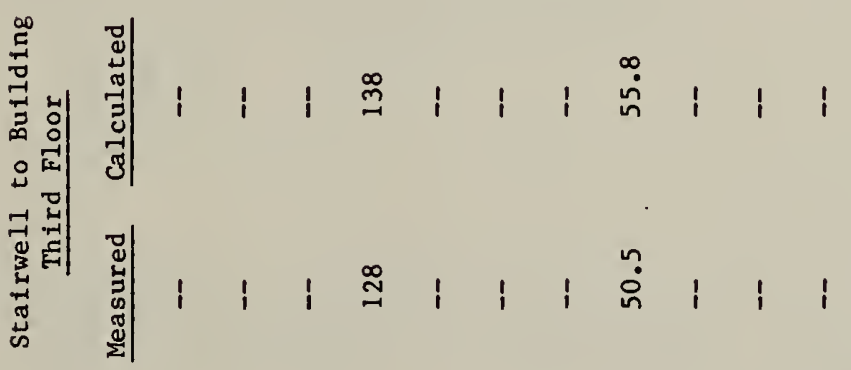

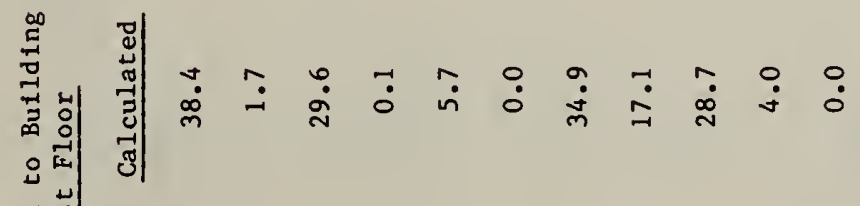

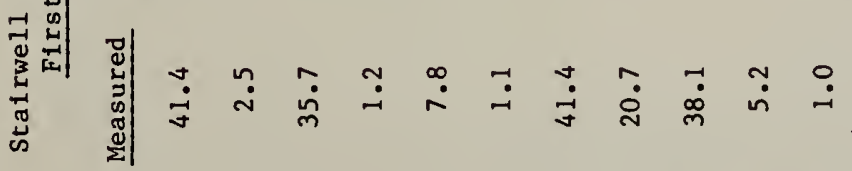

岁 
Table 5. Flow factors from building to the outside based on a flow exponent of $1 / 2$

\begin{tabular}{cc} 
Floor (i) & $\begin{array}{c}\mathrm{K}_{\mathrm{BO} 1} \\
1\end{array}$ \\
\hline $\begin{array}{c}\left(\mathrm{kg} \mathrm{s}^{-1} \mathrm{~Pa}^{-1 / 2}\right) \\
2\end{array}$ & 0.0133 \\
3 & 0.0137 \\
4 & 0.0113 \\
5 & 0.0114 \\
6 & 0.0196 \\
7 & 0.0119
\end{tabular}




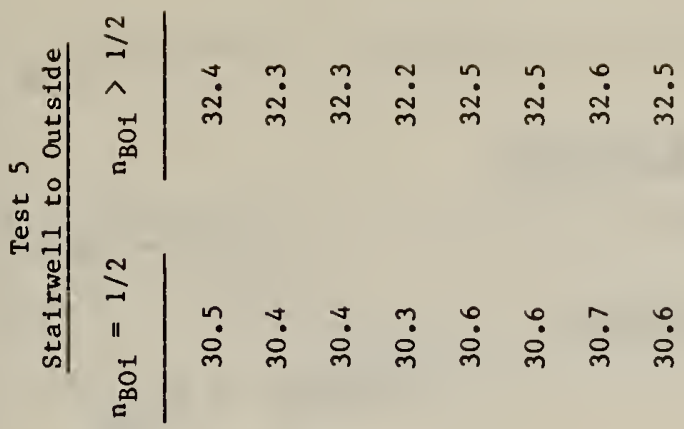

$$
\begin{aligned}
& \stackrel{\Xi}{ \pm}
\end{aligned}
$$

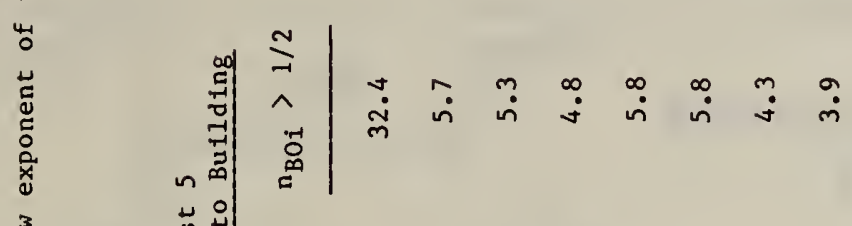

$$
\begin{aligned}
& \text { 章 }
\end{aligned}
$$

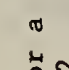

$$
\begin{aligned}
& \text { 范 } \\
& \stackrel{0}{0} \frac{\pi}{0} \\
& \text { 岁苛 }
\end{aligned}
$$

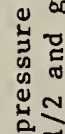

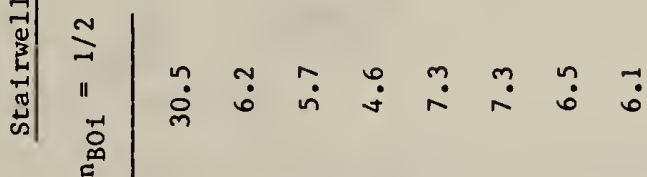

$$
\begin{aligned}
& \text { 告| } \\
& \text { 岁㟧 } \\
& \text { प्यें }
\end{aligned}
$$

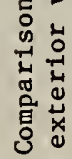

$$
\begin{aligned}
& \text { 竎 }
\end{aligned}
$$

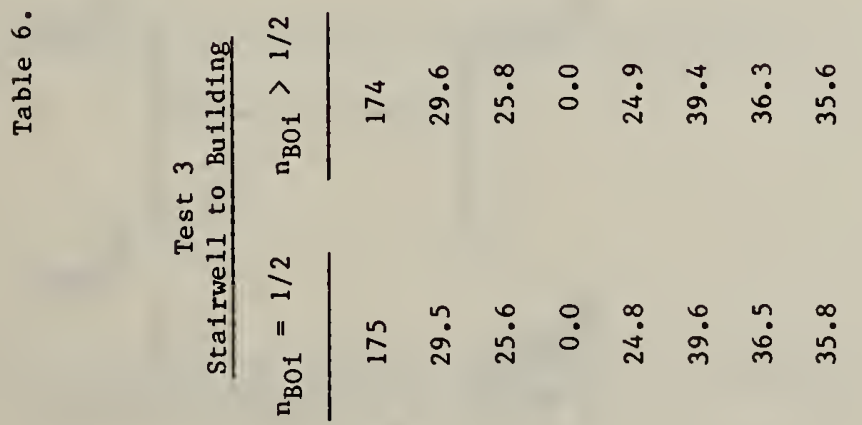

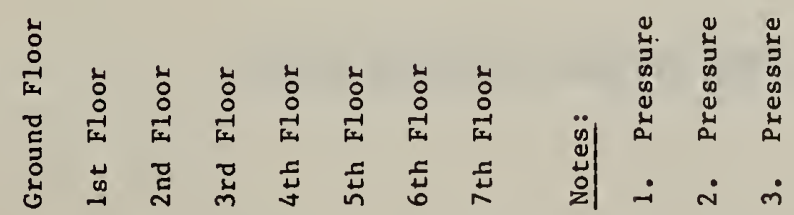


Symbols:

$\mathrm{K}_{\mathrm{BO}}=$ flow factor between bullding and outside on floor $I$.

$K_{F 1}=$ flow factor between floor I and floor i-1.

$\mathrm{K}_{\mathrm{SBI}}=$ flow factor between stalnwell and building on floor $i$.

$\mathrm{K}_{\text {SO; }}=$ floor factor between stainell and outside on floor $i$.

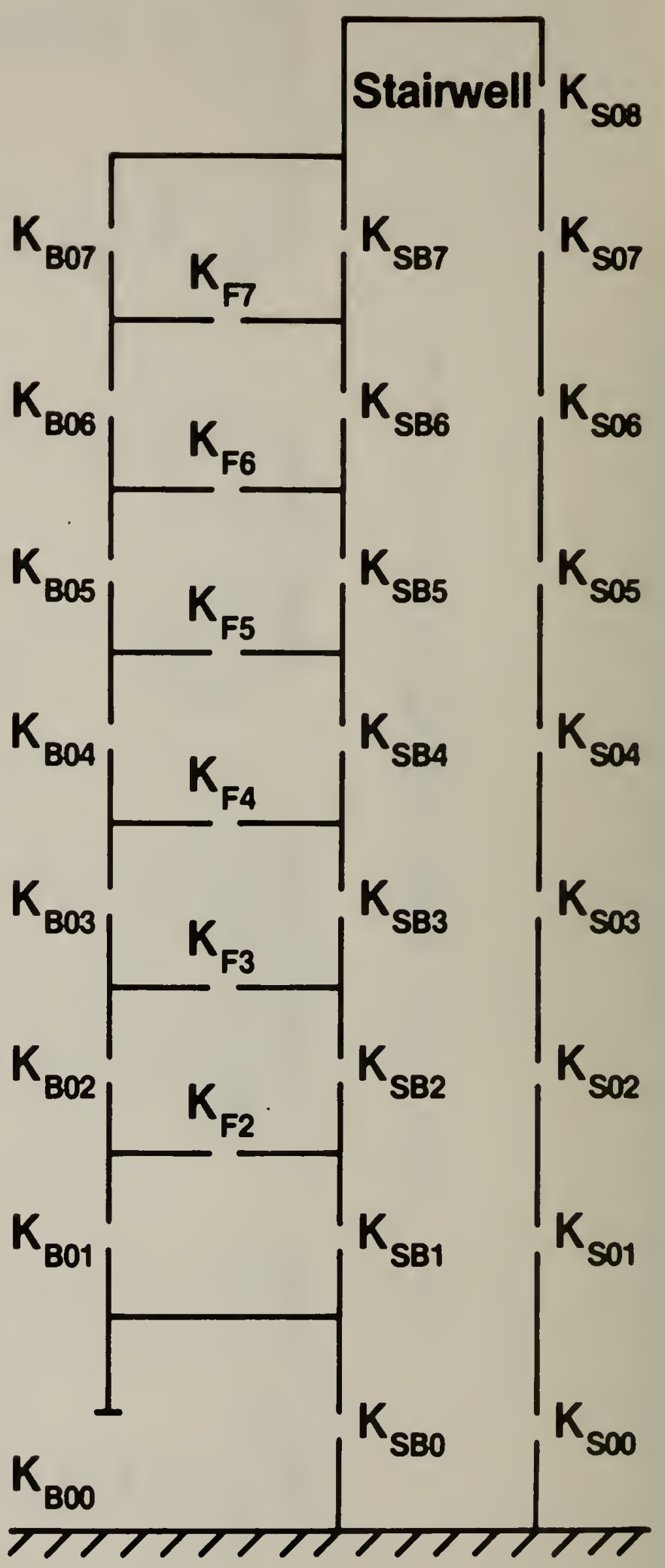

Figure 1. Idealized flow model for CSTB tower. 
This appendix consists of the calculations of the flow factors that were used in the simulations presented in this report. For convenience, a summary of these flow factors is listed in table 2.

As stated in section 2, the air flow through a flow path can be expressed as:

$$
\dot{\mathrm{m}}=\mathrm{K}(\Delta \mathrm{P})^{\mathrm{n}}
$$

When $n=1 / 2$, the mass flow rate of air can be expressed by the orifice equation as:

$$
\dot{\mathrm{m}}=\mathrm{AC} \sqrt{2 \mathrm{p \Delta \textrm {P }}}
$$

where $A=$ flow area

$$
C=\text { flow coefficient }
$$$$
\rho=\text { density of air in the flow path }
$$

Therefore the flow factor can be expressed as

$$
K=A C \sqrt{2 p}
$$

and for the flow in $\mathrm{kg} / \mathrm{s}$ at $21^{\circ} \mathrm{C}$ and 1 atmosphere pressure the flow factor is,

$$
\mathrm{K}=1.55 \mathrm{AC}
$$


In the following calculations, the areas were all measured values and the flow coefficients were generally based upon experience. However, the flow coefficient for the open transom windows was based on flow data obtained from Idel'chik [15]. The flow coefficients used for open doors are discussed in section 4 .

1. Calculate the flow factor, $\mathrm{K}_{\mathrm{SBi}}$, between the stairwell and the building with the doors closed on floors $i=0$ to 7 . The stairwell doors were tightly gasketed and when the doors were closed, virtually all the leakage was through a hole cut in the center of each door.

$$
\begin{aligned}
& \mathrm{A}_{\mathrm{SBi}}=0.025 \mathrm{~m}^{2} ; c=0.65 \\
& \mathrm{~K}_{\mathrm{SBi}}=0.0252
\end{aligned}
$$

2. Calculate the flow factor, $\mathrm{K}_{\mathrm{SBi}}$, when the stairwell door is open on the floors $i=1$ to 7 .

$$
\mathrm{A}_{\mathrm{SBi}}=1.59 \mathrm{~m}^{2}
$$

When the transom window is closed on the floor with the closed stairwell door, the flow through the open doorway is relatively low.

$$
\begin{aligned}
C & =0.60 \\
K_{S B i} & =1.48 \text { when transom window on floor } i \text { is closed }
\end{aligned}
$$


When the transom window on floor $i$ is open, the flow through the open doorway is much larger. In such a case, a flow coefficient of $C=0.30$ is used as explained in section 4 .

$$
\mathrm{K}_{\mathrm{SBi}}=0.739 \text { when transom window on floor } i \text { is open }
$$

3. Calculate the flow factor, $\mathrm{K}_{\mathrm{SBO}}$, from the stairwell to the building on the ground floor when the door is open. Because there is considerable area for leakage from the building to the outside, the flow through the open doorway is relatively large, and therefore a flow coefficient of $C=0.30$ is used.

$$
\begin{aligned}
& \mathrm{A}_{\mathrm{SBO}}=1.35 \mathrm{~m}^{2} \\
& \mathrm{~K}_{\mathrm{SBO}}=0.628
\end{aligned}
$$

4. Calculate the flow factor, $\mathrm{K}_{\mathrm{BO}}$, with the transom window in the exterior wall open.

$$
\mathrm{A}_{\mathrm{BO}}=0.40 \mathrm{~m}^{2}
$$

Because the transom window is open at a $45^{\circ}$ angle, the flow coefficient is chosen as $\mathrm{C}=0.50$.

$$
\mathrm{K}_{\mathrm{BO1}}=0.310
$$


5. Calculate the flow factor, $\mathrm{K}_{\mathrm{SO1}}$, between the stairwell and the outside for $1=0$ to 8 . This calculation is based on Hognon's callbration of the leakage from the stairwell to the outside at $\mathrm{AC}=0.020 \mathrm{~m}^{2}$ for the entire stairwell. This is distributed over the height of the stairwell so that,

$$
\mathrm{K}_{\mathrm{SO}}=0.00344
$$

6. Calculate the flow factor, $K_{F 1}$, for the flow path in floor 1 where $1=2$ to 7. The leakage between floors is through an arrangement of flexible duct and wood boxes as illustrated in figure $\mathrm{Al}$. This arrangement was installed to achieve a calculated flow factor between floors. Other leakage paths between the floors were sealed. The friction loss in the duct was determined to be negligible and the flow factor was expressed as,

$$
\mathrm{K}_{\mathrm{Fi}}=\left[\frac{2}{\mathrm{~K}_{1}^{2}}+\frac{2}{\mathrm{~K}_{2}^{2}}\right]^{-1 / 2}
$$

where $\mathrm{K}_{1}=$ flow factor through the adjustable opening

$\mathrm{K}_{2}=$ flow factor through the inlet (or outlet) of the duct.

The flow coefficient for $K_{1}$ is $C=0.60$ and the flow coefficient for $K_{2}$ is $C=0.80$

$$
\begin{aligned}
& A_{1}=0.021 \mathrm{~m}^{2} \\
& \mathrm{~K}_{1}=0.0195 \\
& \mathrm{~A}_{2}=0.0314 \mathrm{~m}^{2} \\
& \mathrm{~K}_{2}=0.0398 \mathrm{~m}^{2} \\
& \mathrm{~K}_{\mathrm{Fi}}=0.0123
\end{aligned}
$$


7. Calculate the flow factor, $\mathrm{K}_{\mathrm{B} 00}$, between the building and the outside on the ground floor. The connections are shown in figure A2 with the following flow areas $\left(\right.$ in $\left.\mathrm{m}^{2}\right)$ :

$$
\begin{aligned}
& A_{1}=A_{2}=0.80 \times 1.93=1.544 \\
& A_{3}=0.80 \times 1.97=1.576 \\
& A_{4}=1.05 \times 1.75=1.838 \\
& A_{5}=1.05 \times 1.96=2.058 \\
& A_{6}=0.67 \times 1.97=1.320 \\
& A_{7}=0.70 \times 2.00=1.400 \\
& A_{8}=0.90 \times 2.23=2.007 \\
& A_{9}=0.87 \times 1.98=1.723 \\
& A_{10}=0.70 \times 2.20=1.540 \\
& A_{11}=0.87 \times 1.82=1.583 \\
& A_{12}=4(1.10 \times 0.90)=3.960 \\
& A_{13}=1.10 \times 0.90=0.990 \\
& A_{14}=2.0 \text { a pproximate area } \\
& A_{15}=1.10 \times 0.90=0.990 \\
& A_{16}=0.70 \times 2.00=1.400
\end{aligned}
$$

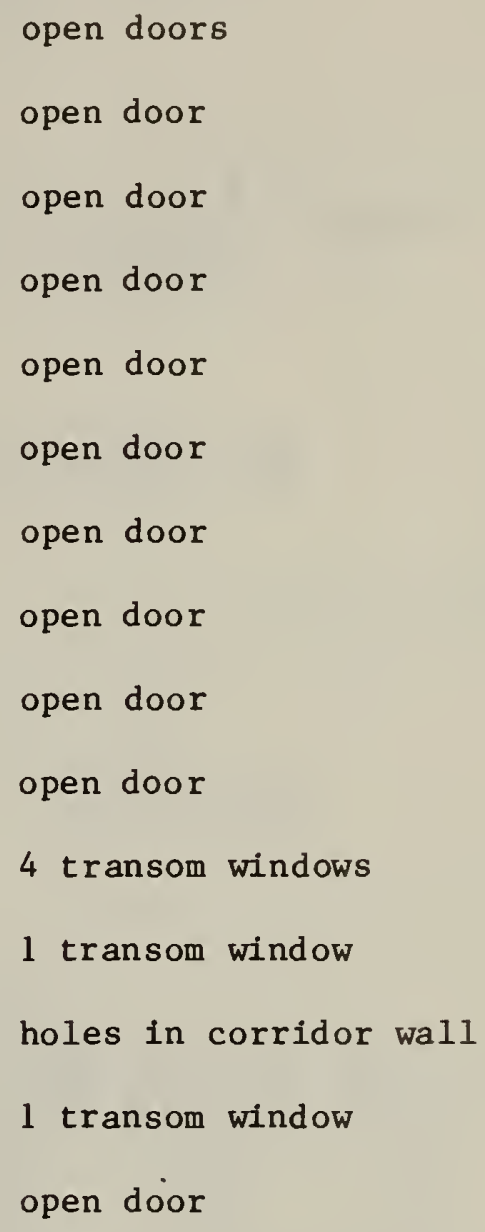

The approach is to calculate the equivalent area, $A_{e}\left(\right.$ in $m^{2}$ ), of the system as follows :

$$
\begin{aligned}
& A_{1,2,3,4}=\left[\frac{1}{\left(A_{1}+A_{2}\right)^{2}}+\frac{1}{A_{3}^{2}}+\frac{1}{A_{4}^{2}}\right]^{-1 / 2}=1.116 \\
& A_{14,15}=\left[\frac{1}{A_{14}^{2}}+\frac{1}{A_{15}^{2}}\right]^{-1 / 2}=0.887
\end{aligned}
$$




$$
\begin{gathered}
A_{5,6,7,8}=\left[\frac{1}{A_{5}^{2}}+\frac{1}{A_{6}^{2}}+\frac{1}{A_{7}^{2}}+\frac{1}{A_{8}^{2}}\right]^{-1 / 2}=0.798 \\
A_{11,13,16}=\left[\frac{1}{A_{11}^{2}}+\frac{1}{A_{13}^{2}}+\frac{1}{A_{16}^{2}}\right]^{-1 / 2}=0.720 \\
A_{5-13,16}=\left[\frac{1}{\left(A_{5,6,7,8}+A_{9}\right)^{2}}+\frac{1}{\left(A_{10}+A_{12}\right)^{2}}+\frac{\left(A_{11,13,16}\right)^{2}}{1 / 2}=0.687\right. \\
A_{e}=A_{1,2,3,4}+A_{14,15}+A_{5-13,16}=2.69
\end{gathered}
$$

For $C=0.60$

$\mathrm{K}_{\mathrm{B} 00}=2.50$ 


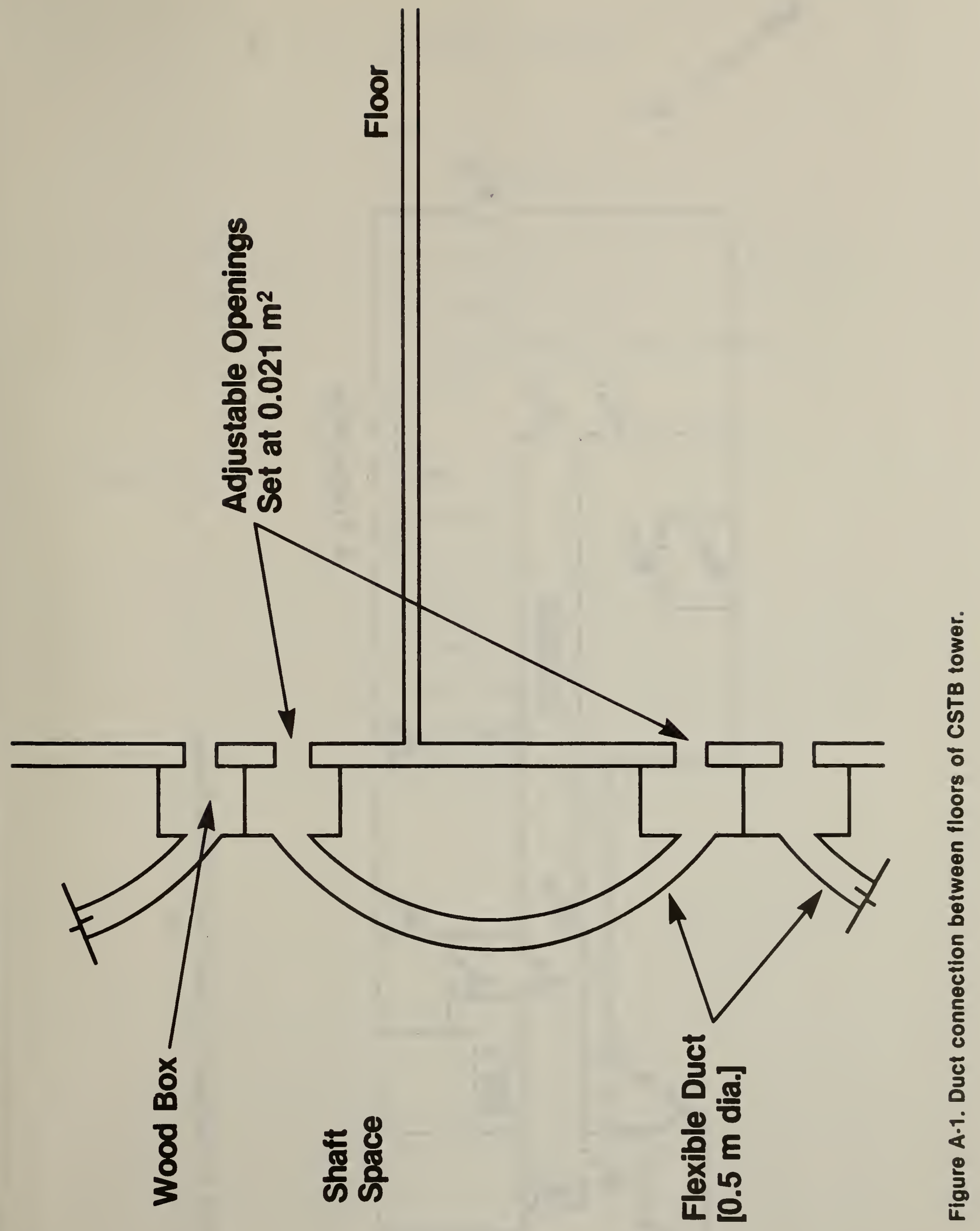



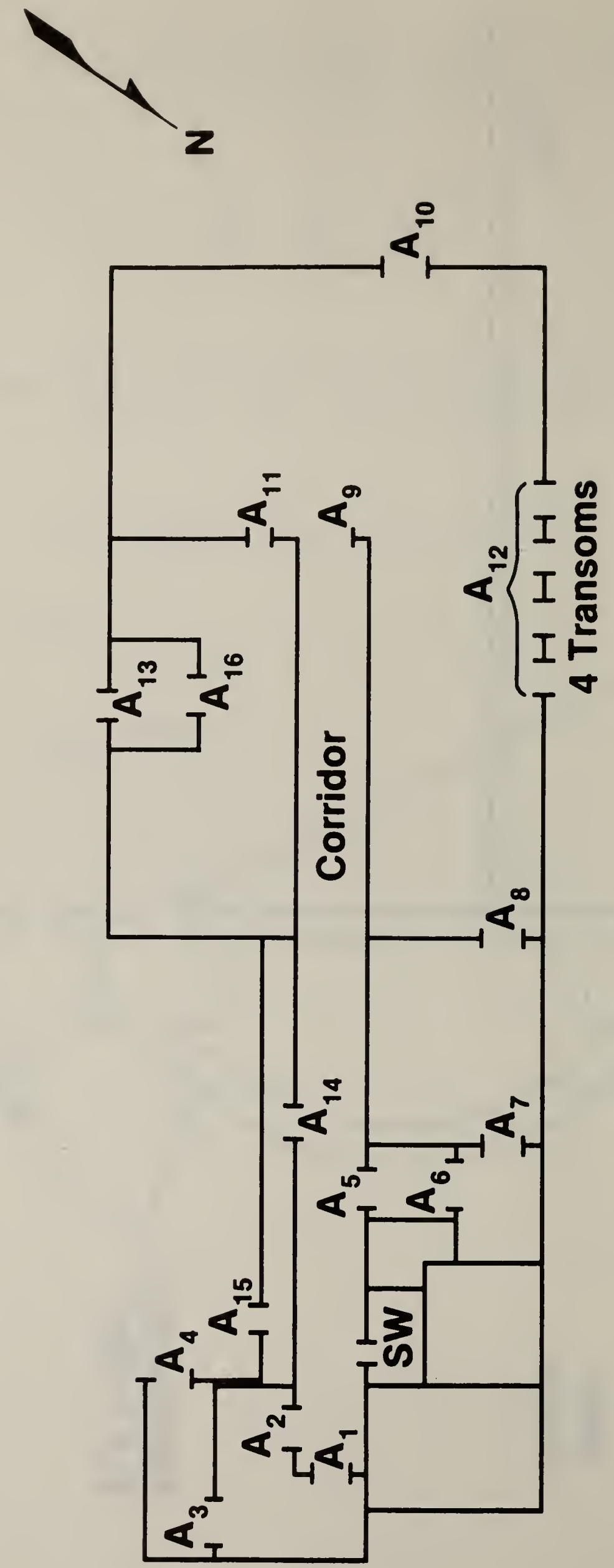

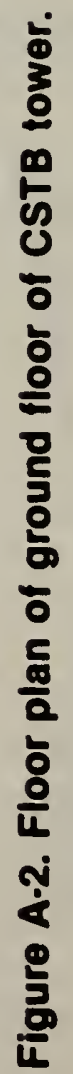


APPENDIX B. NOTATION

A

C

K

$\dot{\mathrm{m}}$

n

$\Delta \mathrm{P}$

$\rho$

Subscripts:

B

F

0

S

i

0 flow area

flow coefficient

flow factor

mass flow rate

flow exponent

pressure difference across flow path

density

building

floor

outside

stalrwell

floor level

ground floor 


\section{APPENDIX C. UNIT CONVERSIONS}

$$
\begin{aligned}
& 1 \mathrm{nl}=3.28 \mathrm{ft} \\
& 1 \mathrm{~Pa}=0.00402 \mathrm{in} \mathrm{H}_{2} \mathrm{O} \\
& 1 \mathrm{~kg}=0.4541 \mathrm{~b} \text { mass } \\
& 1 \mathrm{~km} \mathrm{~h}-1=0.621 \mathrm{mph} \\
& 1 \mathrm{~m} / \mathrm{s}=197 \mathrm{ft} / \mathrm{mtn}
\end{aligned}
$$


NBS-114A (REV, 2-8C)

U.S. DEPT. OF COMM.

BIBLIOGRAPHIC DATA

SHEET (See in structions)
1. PUBLICATION OR REPORT NO. NBSIR $83-2737$
2. Performing Organ. Report No

3. Publication Date

August 1983

4. TITLE AND SUBTITLE

Computer Analysis of a Pressurized Stairwell

\section{5. $\operatorname{AUTHOR}(S)$}

John H. Klote and Xavier Bodart

6. PERFORMING ORGANIZATION (If joint or other than NBS, see instructions)

7. Contract/Grant No.

NATIONAL BUREAU OF STANDARDS and

Centre Scientifique et

Technique du Batiment

DEPARTMENT OF COMMERCE

WASHINGTON, D.C. 20234

Station de Recherche

Champs Sur Marne, France

9. SPONSORING ORGANIZATION NAME AND COMPLETE ADDRESS (Street, City. State, ZIP)

8. Type of Report \& Period Covered

10. SUPPLEMENTARY NOTES

Document describes a computer program; SF-185, FIPS Software Summary, is attached.

11. ABSTRACT (A 200-word or less factual summary of most significant information. If document includes a significant bibliography or literature survey. mention it here) In recent years pressurized stariwells have been incorporated in buildings in a effort to provide smoke free exits during building fires. This paper compares the results of tests conducted in a pressurized stairwell at Champs Sur Marne, France, with computer analysis using a computer code developed at the National Bureau of Standards (NBS). A second paper is planned which will compare the NBS program with the Centre Scientifique et Technique du Batiment (CSTB) program for the same series of tests. Agreement between the NBS computer simulation and the test data was good for all tests analyzed. The appropriateness of using exclusively a flow exponent of $\frac{1}{2}$ for smoke control design is reevaluated, and is found to have only a slight effect on the results of a computer simulation.

12. KEY WORDS (Six to twelve entries; alphabetical order; capitalize only proper names; and separate key words by semicolons)

Air movement; computer programs; egress; elevator shafts; escape means; modeling; pressurization; simulation; smoke control; stairwells.

13. AVAILABILITY

$X^{U n l i m i t e d}$

$\square$ For Official Distribution. Do Not Release to NTIS

$\square$ Order From Superintendent of Documents, U.S. Government Printing Office, Washington, D.C. 20402.

X Order From National Technical Information Service (NTIS), Springfield, VA. 22161

14. NO. OF PRINTED PAGES

34

15. Price

$\$ 8.50$ 


